\title{
"No country but the ocean": Reading International Law from the Deck of an Indian Ocean Dhow, ca. 1900
}

\author{
FAHAD AHMAD BISHARA \\ Corcoran Department of History, University of Virginia
}

On 12 April 1893, the Zanzibar Gazette described an incident that had taken place the previous Sunday afternoon. British officers on the island had spotted a dhow ${ }^{1}$ sailing out of the harbor under the French flag. The authorities dispatched a British naval officer, who discovered more than fifty slaves tucked away in a hatch. The article continued: "The owners of the dhow were Arabs from Oman, and the destination was to be the Persian Gulf." But despite the discovery of suspected slaves on board the vessel, the search party's hands were tied: "As the dhow sailed under the French flag," the author of the piece lamented, the naval officer "proceeded to the French consulate and surrendered the dhow to the French consul." $" 2$ This incident was but one of many that occurred around the Western Indian Ocean. Over the last two decades of the nineteenth century, British officers in Zanzibar, Aden, Muscat, and Dubai regularly encountered suspected Arab slave traders who sailed under the French flag and possessed French papers. Officers frequently complained about their inability to apprehend the suspects; only the French consul had the jurisdiction to search and seize the dhows, and it was not always clear that he had either the means or inclination to do so.

\footnotetext{
Acknowledgments: The author would like to thank the editors at CSSH and the journal's anonymous reviewers for their enormously helpful comments. Special thanks, too, to participants at the Ocean of Law workshop held at Leiden in 2015, and the NYU Islamic Law in Society workshop, as well as the members of the legal history writing group at the University of Virginia. This article also benefited from comments from Noora Lori and Daragh Grant, and from research support provided by the Social Science Research Council and the Joint Center for History and Economics at Harvard University.

${ }^{1}$ The term "dhow" refers to a range of different native sailing ships in the Indian Ocean, most of which utilized a lateen sail.

2 "Local News," Gazette for Zanzibar and East Africa (12 Apr. 1893): 2.
} 
The overwhelming majority of these dhows, it became clear, hailed from the port of Sur, a small dhow port on the southeast corner of the Arabian Peninsula, roughly 100 miles from the capital, Muscat. By the century's end, Sur was home to about twelve thousand inhabitants. ${ }^{3}$ For a port of its size, Sur had quickly developed an oversized reputation as an entrepôt for slaves coming to Arabia from East Africa, and at least in the British official imagination, Sur was synonymous with the slave trade. British naval expeditions in the century's last decades often consisted of chasing Suri dhows around the northwestern Indian Ocean and failing to apprehend them, if not because their captains (called nakhodas) ran the vessels aground and chased their slave cargo into the interior, then because they raised the French flag to prevent officers from searching the ship.

By the beginning of the twentieth century, the issue had reached such proportions that the British Government, after several failed attempts to convince the French Consul in Muscat to stop issuing papers to Suri dhows, decided to take the matter to the newly formed Permanent Court of Arbitration in The Hague. At the court the British government, through its hired representative the United States Supreme Court Justice Melville Fuller, argued that France's actions contravened three different layers of legislation: it violated the Brussels Act, part of which laid out a series of rules designed to cripple the slave trade in the Western Indian Ocean; it violated French treaties with the Sultan of Muscat, which limited French consular jurisdiction to French subjects and their employees; and it contravened its own maritime laws that laid out the circumstances under which French consuls could grant papers to ships. ${ }^{4}$ France, the British argued, was flagrantly violating all established principles of international law and imperial jurisdiction.

For its part, the French government claimed that its right to grant flags and passes to Suri dhows stemmed from a less clearly defined jurisdictional landscape. Conditions for subjecthood in Oman, the French argued, were indefinite and unascertained, and, they asserted, Oman, as a Muslim power, might be considered as analogous to the Ottoman Empire and thus subject to capitulatory relations with European states. ${ }^{5}$ Even by principles of international law, then, Suri nakhodas could legitimately fly the French flag. More interestingly, however, the French Consul claimed that the Suri mariners belonged not to the Sultan of Muscat or to any territorial sovereign, but rather were members of a maritime community that transcended any of these. The mariners, he

3 J. G. Lorimer, Gazetteer of the Persian Gulf, Oman, and Central Arabia, vol. 2 (Archive Editions, 1987), 1847-48.

4 The Case on Behalf of the Government of His Britannic Majesty and of His Highness the Sultan of Muscat (1904), 23-29.

${ }_{5}$ Lorimer, Gazetteer, vol. 1 (Historical), 567-68. 
claimed, had "no country but the ocean" (n'ayant pas d'autre patrie que l'Ocean). ${ }^{6}$

Historians of the Indian Ocean who have noticed the Muscat Dhows case have tended to index the matter as one grounded in the issue of slavery. ${ }^{7}$ There is no reason not to, since the case file is chock-full of concerns about how the French flag was being used as a cover for slave traders, and the narratives that we have from British naval cruisers in the Indian Ocean primarily focus on the slave-trading activities of dhow captains. And of course the nakhodas were hardly innocent of involvement in the slave trade: the marginalization of the dhow trade over the course of the second half of the nineteenth century, coupled with the expansion of plantation agriculture in East Africa and South Arabia and a pearling boom in the Persian Gulf, created plenty of incentives for a prospective slave trader. ${ }^{8}$

But in some ways the slavery issue is a red herring. At its core, the case was about law and empire: participants at all stages of the trial raised questions surrounding imperial and extraterritorial jurisdiction, maritime law, and international conventions. These were the issues that mattered to the actors involved, and this was why the case went to The Hague. The matter of slavery, which the British Government so deftly worked through its public relations machinery at home and abroad, was window dressing. Slavery was what British officials wanted the case to be about; their attempts to spin the issue reeked of past invectives against pirates, smugglers, and slave traders that imperial powers had for centuries leveled against actors whom they wanted to regulate. But many of the reports on dhows and flags had nothing to do with slavery as such. For actors at the time, the matter was fundamentally about a changing global legal regime; anti-slavery laws were an important element of this regime, but could hardly account for all of it.

In this article, I am not much interested in the decisions handed down in the court, nor do I feel compelled to pronounce the Suri nakhodas guilty or innocent of involvement in the slave trade. Instead, I wish to understand the claims that nakhodas made about their right to the French flag, and what these claims (and the practices they engaged in) might mean for our understanding of Indian Ocean maritime life in the age of empire and a growing

\footnotetext{
6 Boutres Mascatais Francais: Memoire (1904), 10.

7 For the most recent account, see Matthew Hopper, Slaves of One Master: Globalization and Slavery in Arabia in the Age of Empire (Yale University Press, 2015), 160-61. Briton Cooper Busch sees it as connected to, but not necessarily revolving around, the slave trade; Britain and the Persian Gulf, 1894-1914 (University of California Press, 1967), 154-86. By contrast, for Abdul Sheriff, the case highlights the dense web of social connections around the Indian Ocean, in Dhow Cultures of the Indian Ocean (Columbia University Press, 2010), 57-60. Johan Mathew's take is a little different, and he grounds the case in a changing regional economy, in Margins of the Market: Trafficking and Capitalism across the Arabian Sea (University of California Press, 2016), 34-38.

${ }^{8}$ Hopper, Slaves, 51-104.
} 
body of international law. I want to unpack the legal consciousness of an itinerant commercial community in a time of increasing imperial surveillance and hardening jurisdictional boundaries in the Indian Ocean. The claims Suri nakhodas articulated and the practices they engaged in at sea reveal a maritime legal culture at work, one animated by a long history of encountering regional and global empires at sea. As it took root in legal technologies like papers and flags, international law became something that actors could integrate into their own worlds, vernacularizing it in their speech and domesticating it through their actions as they navigated a changing imperial seascape. By unpacking the legal consciousness of Suri nakhodas, I show how a regime of international law manifested itself in an oceanic world that ran thick with legal idioms.

In unpacking the case, I draw from an emerging body of scholarship that explores the intersections of materiality, bureaucracy, and politics and has charted the role that paperwork plays in enabling or subverting authority. "Paperwork," one scholar points out, "is full of surprises"; it "syncopates the state's rhythms, destabilizes its structures." Scholars in media studies, anthropology, and history have all illustrated the insights that can be realized from looking at bureaucratic objects rather than through them, exploring the role that documents themselves play in mediating the relationship between states, ideologies, and everyday actors. ${ }^{10}$ In doing so, they have raised new questions about the process through which power is instantiated in mundane bureaucratic settings. One particularly compelling idea is Matthew Hull's notion of graphic ideologies, "sets of conceptions about graphic artifacts held by their users." These can include a wide-ranging set of notions about artifacts themselves, including the relationship between the material qualities of an artifact and its authority, or its capacity to produce truth. Here, the official discourse surrounding the artifact and its purposes is just one of many graphic ideologies. ${ }^{11}$

But this paper is more than a media history of the Muscat Dhows case; it is a microhistory of that case. Instead of taking the case as a whole - all of the negotiations, imperial wrangling, and arguments presented in court-I take one small set of petitions from the case and use it to delve into the broader encounter between Indian Ocean mariners and European empires. I call it a microhistory in part because of the greatly reduced scale of the analysis, but also because the article broadly follows the microhistorical method in unpacking ostensibly idiosyncratic documents and following the clues they offer so as

9 Ben Kafka, The Demon of Writing: Powers and Failures of Paperwork (Zone Books, 2012), $9-10$.

${ }^{10}$ See also Kathryn Burns, Into the Archive: Writing and Power in Colonial Peru (Duke University Press, 2010); Lisa Gitelman, Paper Knowledge: Towards a Media History of Documents (Duke University Press, 2014); Matthew Hull, Government of Paper: The Materiality of Bureaucracy in Urban Pakistan (University of California Press, 2012); Cornelia Vismann, Files: Law and Media Technology (Stanford University Press, 2008).

${ }^{11}$ Hull, Government of Paper, 14-16. 
to gain a clearer understanding of the broader stakes involved. ${ }^{12}$ The strength of microhistory is in part its impulse to pay attention to moments of confusion or rupture, ones that allow us to see how different actors imagine their world to work and thus help bring into the open structures that would otherwise be difficult to see. In conceiving of this as a microhistory of the Muscat Dhows case, we might then recapture the original spirit of the enterprise, which sought to challenge prevailing paradigms and shake (if not entirely undermine) the foundations of existing grand narratives. ${ }^{13}$ Microhistorians, we must be reminded, "are actually trying to discover very big things with their microscopes and magnifying lenses.",

A conceptual toolkit that joins insights from legal anthropology and media studies together with the microhistorical method has far-ranging implications for the study of the legal encounters between empires and those whom they sought to govern and, by extension, for the study of international law. The words and actions of the Suris clash with received narratives of international law - of imperial jurisdiction, of geography, and of an international legal order more broadly. And yet, by placing these actors and their surprising statements at the center of the narrative, we can arrive at a different, more grounded way of thinking about international legal order and how it instantiated itself in the legal consciousness of those who were at the margins of that order-a picture of international law that is grounded in the practices and discourses that gave it meaning in the vernacular.

Legal anthropologists have long pointed out that international law does not take root in the abstract, but requires a process of translation into local categories, of vernacularization, by which global legal regimes become localized through the meanings, signs, and practices of local places. ${ }^{15}$ How vernacularization takes shape in different junctures depends on a variety of different factors, including social and power relations between different actors, the characteristics of the channels through which ideas and practices flow, and the nature of the discourses in which they are embedded. ${ }^{16}$ The conceptual framework of vernacularization has underscored the role that local agents play in making international human rights laws and ideas applicable in local contexts,

\footnotetext{
12 Matti Peltonen, "Clues, Margins, and Monads: The Micro-Macro Link in Historical Research," History and Theory 40 (2001): 347-59.

13 Francesca Trivellato, "Is There a Future for Italian Microhistory in the Age of Global History?" California Italian Studies 2, 1 (2011): section 8.

14 Peltonen, "Clues," 350.

15 Sally Engle Merry, "Legal Vernacularization and Ka Ho'okolokolonui Kanaka Maoli, The People's International Tribunal, Hawai`i, 1993," Political and Legal Anthropology Review 19, 1 (1996): 67-82, 80. More broadly, see Merry's Human Rights and Gender Violence: Translating International Law into Local Justice (University of Chicago Press, 2006), 1-35.

${ }^{16}$ Peggy Levitt and Sally Engle Merry, "Vernacularization on the Ground: Local Uses of Global Women's Rights in Peru, China, India and the United States," Global Networks 9, 4 (2009): 441$61,446$.
} 
and also the process through which gendered notions of the nation-state are reinforced throughout the process. ${ }^{17}$

Here I will take a different tack and highlight, instead, the processes through which imperial/international legal instruments were incorporated into the graphic ideologies and practices of an itinerant maritime community. In examining the actions and statements of Suri nakhodas more closely-by bringing, in short, a microhistorical perspective to the case-we can deepen the category of vernacularization so that it includes the processes through which actors made artifacts familiar or usable, and drew them into intimate circuits of exchange and meaning-making. These were processes of domestication that went beyond simple translations into vernacular categories. ${ }^{18}$ International legal artifacts like flags and passes only took root when they were domesticated, when they were brought into the orbit of regional historical and geographical imaginaries and the practices of exchange that underpinned them. The actions taken by Suri nakhodas were neither isolated nor idiosyncratic and they had tremendous implications for how international and imperial law took shape on the high seas, up to and during the Muscat Dhows case, but also in its legal afterlives. The history of international law more broadly might thus be thought of as a regime that was "both founded and confounded by its encounters with" regional regimes of paper. ${ }^{19}$

\section{BINDING THE WAVES}

As a legal phenomenon, the issue of flag-raising at sea and the problems of sovereignty and jurisdiction that it brought up have had a troubled past. Few issues have highlighted the tensions between the modern state system and the anomalous legal geography of the high seas as clearly as the matter of flags of convenience: an international arrangement "whereby some countries ... allow the use of their flags by foreign shipping by a simple administrative formality, such as the mere registration or the grant of a certificate of registry." ${ }^{20}$ Commonly, these have been smaller countries-Panama, Liberia, Lebanon, Honduras, and others - that have made the registration of ships easy and have little in the way

17 Sealing Cheng, “The Paradox of Vernacularization: Women's Human Rights and the Gendering of Nationhood," Anthropological Quarterly 84, 2 (2011): 475-505.

${ }_{18}$ See especially Jeremy Prestholdt, Domesticating the World: African Consumerism and the Genealogies of Globalization (University of California Press, 2008), 8. See also Alison Stenning, Adrian Smith, Alena Rochovskà, and Dariusz Świątek, Domesticating Neo-Liberalism: Spaces of Economic Practice and Social Reproduction in Post-Socialist Cities (Wiley-Blackwell, 2010), $72-74$.

19 Kafka, Demon of Writing, 10.

20 C. J. Colombos, The International Law of the Sea, 4th ed. (Longmans, 1959), 336. Surprisingly little academic attention has been paid to flags of convenience. The most comprehensive legal study to date is Boleslaw Adam Boczek's Flags of Convenience: An International Legal Study (Harvard University Press, 1962). Another good study is Rodney Carlisle's Sovereignty for Sale: The Origins and Evolution of the Panamanian and Liberian Flags of Convenience (Naval Institute Press, 1982). 
of labor regulations, and have done little to hold the captains of those vessels accountable for their actions at sea. The result has been a self-defeating system: the regime relies on states to police the activities of ships sailing under their flags, but those same states lack the resources or wherewithal to do so.

The problem has not yet found any clear resolution. In a series of articles published in the New York Times in the summer of 2015, journalists highlighted the difficulty of prosecuting crimes that take place in international waters. Tracking the illicit activities of a number of different ships, ranging from illegal fishing to the use of what amounts to slave labor, the authors state outright that the flagging system "provides a good cover for the unscrupulous" since most flagging countries have no navies that patrol beyond their national waters and most international organizations have too small a stake in the matter to pursue it. ${ }^{21}$ The articles make clear that the high seas remain an anomalous legal zone even in a twenty-first-century world characterized by dozens of international organizations, scores of treaties and conventions, and an admission by all but the most hardened of international relations theorists that this is a truly transnational legal order. The author of one recent law journal article called the issue of flags of convenience a "jurisdictional quandary" and emphasized the need to re-envision the maritime legal regime in order to bring it in line with the ideals of an international community. ${ }^{22}$

But flags of convenience were not always so inconvenient. At different historical junctures, ground (or sea?) level legal artifacts like flags or passes formed the arteries through which imperial sovereignty pulsed on the high seas. ${ }^{23}$ While at sea, ship captains looking to catch a lawful prize (or escape the attention of a potential enemy ship) thought nothing of keeping several sets of flags and papers aboard their ships and disguising themselves as members of one European nation or another. Through the artful manipulation of flags and papers, they navigated the fluid boundary between lawful and unlawful prize capture in the Atlantic and Indian oceans at a time when those statuses were still being worked out in Europe itself. ${ }^{24}$

In the Indian Ocean, the question of flag-raising and what status it conferred onto a ship at sea had been raised several times during the nineteenth century. In the wake of Napoleon's failed Egyptian expedition, the Sultan of

${ }^{21}$ Ian Urbina, "The Outlaw Sea, Part 1: Stowaways and Crimes aboard a Scofflaw Ship," New York Times, 17 July 2015.

${ }^{22}$ Eric Powell, "Taming the Beast: How the International Legal Regime Creates and Contains Flags of Convenience," Annual Survey of International and Comparative Law 19, 1 (2013): $263-300$.

${ }^{23}$ Lauren Benton, "Legal Spaces of Empire: Piracy and the Origins of Ocean Regionalism," Comparative Studies in Society and History 47, 4 (2005): 700-24.

${ }^{24}$ See also Robert C. Ritchie, Captain Kidd and the War against the Pirates (Harvard University Press, 1986), 104, 106-7; and Nathan Perl-Rosenthal, Citizen Sailors: Becoming American in the Age of Revolution (Harvard University Press, 2015), esp. 33-43. 
Muscat - whom both the British and French had been courting — was treated as a neutral, and many British ships sailed under Muscat's flag to avoid harassment. $^{25}$ Indeed, it was not at all uncommon for East India Company ships in the 1790s and 1800s to sail under the red Arab flag, largely to avoid contact with French privateers. ${ }^{26}$ Local shippers also used the Company flag from time to time: in the Straits of Malacca, the Company often granted its flags to local merchants as a favor, knowing well that they would allow for smoother sailing in contested waters. In the Persian Gulf, Indian traders would sometimes ship their merchandise under British colors or with British passes for protection; if attacked, they could then appeal to the Company to help restore their property. $^{27}$ From early on, then, it was clear to actors around the Indian Ocean that a flag or a pass signaled a ship's legal status and that this status was malleable. Ships raised and lowered different colors with relative ease, illustrating the degree to which different protection circuits could form a broader regime.

Imperial powers would also issue flags to dhows and other "native craft" as part of a broader strategy of imperial competition. According to one British intelligence officer-cum-historian writing in the early twentieth century, French authorities in Nosy Be and Mayotte (islands off Madagascar's northwestern coast) had begun "to issue French papers to owners of native vessels who were not French subjects" as early as 1860 as a means of advancing French influence. $^{28}$ By 1868, the British political agent at Zanzibar pointed out to the sultan the "emergency" of Zanzibari vessels being placed under the French flag without his authority. ${ }^{29}$ Just a year later, British officials reported that "nearly every native vessel to the south of Zanzibar now sailed under French colors." 30 British officials suspected that the French were doing this to undermine British influence in the region. The two had, after all, been jostling with one another for colonies and allies around the region for much of the nineteenth century, as the echoes of the Napoleonic Wars reverberated into the Indian Ocean.

But evidence suggests that more was at stake than competition between rival powers in the Indian Ocean. For even when it came to issuing flags and passes to their own subjects, imperial powers like the British were conflicted. In one instance, the advocate general in India asked the political agent at

25 John C. Wilkinson, The Arabs and the Scramble for Africa (Equinox Publishing, 2015), 43.

${ }^{26}$ Charles E. Davies, The Blood-Red Arab Flag: An Investigation into Qasimi Piracy, $1797-$ 1820 (University of Exeter Press, 1997), 109, 144, 278, 283.

27 Nurfadzilah Yahaya, "Legal Pluralism and the East India Company in the Straits of Malacca during the Early Nineteenth Century," Law and History Review (Nov. 2015): 945-64; Davies, Blood-Red Arab Flag, 298, 302, 306.

${ }^{28}$ Lorimer, Gazetteer, vol. 2, 548.

29 Political Agent, Zanzibar, to Seyyid Majid, 10 Dec. 1868, Zanzibar National Archives, AA $3 / 22$.

${ }^{30}$ Lorimer, Gazetteer, vol. 2, 548. 
Zanzibar in 1868 to stop issuing Consular passes granting permission to Indians residing in that port to fly the English flag over their ships. Although the political agent agreed to stop, he pointed out that the practice had gone unchecked for several years and was necessary to prevent British cruisers from capturing vessels belonging to British Indian subjects and protected persons. ${ }^{31}$ The matter reflected the confusion surrounding the boundaries of British imperial subjecthood in the Indian Ocean as much as it did any abstract notion of rights: at stake was whether Indians residing in the sultan's dominions in East Africa were to be considered British subjects, an issue that would find no clear resolution for at least another decade. ${ }^{32}$

Like the question of the boundaries of British Indian subjecthood, the issue of flag-raising was increasingly bound up in a set of geopolitical and economic transformations that characterized the second half of the nineteenth century and had an enormous impact on the place of dhows and their crews in the regional economy. As the British imperial presence in India became more entrenched, and with the opening of the Suez Canal in 1869, the region witnessed a steadily increasing traffic of steamships between Bombay and dozens of ports around the Western Indian Ocean. Though the steamships did not completely displace the dhows, they did push the dhow traffic to the margins of the commercial arena. The subsidies and political patronage that shipping companies enjoyed, in addition to the mergers they engaged in, ensured that they would not only compete with dhows for regional freight, but overtake them altogether, at least on the main routes.

As dhows became increasingly sidelined as Indian Ocean carriers, British officials came to associate them with illicit forms of economic activity such as the slave trade, and also gold smuggling, gun-running, and piracy. The dichotomy between the dhow and the steamship became all the more apparent in the minds of colonial officials around the Western Indian Ocean: steamships formed a component of a new global economy, while dhows were an inconvenient legacy of an irrational, antiquated economic past. ${ }^{33}$ As elsewhere, the rise of industrial capitalism and increasing anxieties about the slave trade went hand in hand, and if Sur and its nakhodas became associated with the slave trade, it was but one expression of a broader economic and discursive shift taking place around the Indian Ocean. ${ }^{34}$ The Suris were just the latest targets in a long

\footnotetext{
31 Political Agent, Zanzibar, to Secretary to the Government, Bombay, 24 Apr. 1869, Maharashtra State Archives, Political Department, vol. 156.

32 Fahad Ahmad Bishara, A Sea of Debt: Law and Economic Life in the Western Indian Ocean, 1780-1950 (Cambridge University Press, 2017), 114-24.

33 Mathew, Margins of the Market; see also Erik Gilbert, Dhows and the Colonial Economy of Zanzibar, 1860-1970 (James Currey, 2004), esp. 59-83.

34 On industrial capitalism and anti-slavery efforts, the touchstone work is Eric Williams, Capitalism and Slavery (University of North Carolina Press, 1944).
} 
history of efforts to regulate activity around the Indian Ocean to make it conform to imperial visions of political economy.

As part of their anti-slavery efforts in the Indian Ocean, the British government engaged in a series of treaties with rulers around the region, bolstering their authority among their subjects in return for commitments to outlaw the maritime trade in slaves (the internal slave trade was largely left alone). ${ }^{35}$ The first to get this treatment, and most relevant to our discussion here, was Sayyid Sa'id bin Sultan Al-Busa'idi, the Sultan of Muscat and Zanzibar, whose reign the British constantly perceived to be plagued with jurisdictional gaps and confusions. Writing from Zanzibar in 1841, British Consul Atkins Hamerton recalled to his superiors in Bombay how, upon his arrival, the inhabitants of the island asked him if he had come to emancipate the slaves and suppress the slave trade. "I turned the subject," Hamerton wrote, "by replying that I was astonished to observe how little the people here regarded His Highness's authority." To this comment, the sultan replied that Hamerton "knew how he was situated ... and [that] his authority over the people here was very trifling indeed." 36

For Sa'id, treaties with the British to suppress the slave trade served the purpose of "validating his expansionist dreams but [were] otherwise window dressing." 37 He could hardly hope to enforce the treaties on land, let alone on the high seas; his authority, it was clear, relied on the cooperation of dozens of clan leaders, merchants, chiefs, and other local rulers. Even in the town of Zanzibar itself, the authority of the sultan was openly flaunted by the seasonal dhow crews arriving from the Persian Gulf and South Arabia, many of whom busily went about smuggling slaves back to their home ports. ${ }^{38}$ As late as the 1890 s, if the sultans exercised any territorial jurisdiction beyond Muscat and Zanzibar, it was largely due to British backing and the cooperation of local chiefs and other authorities.

Within this context, British dealings with the Omani sultans might correctly be seen as growing out of a distinctly Westphalian legal episteme that emphasized the sovereign, territorial state as the primary actor in the international arena. Such a state not only displayed all of the trappings of a positive legal order, but also regularly and effectively exercised its authority within a delineated territory. ${ }^{39}$ This was, in part, what British officials hoped to

\footnotetext{
35 Matthew Hopper, Slaves, 148-63; J. B. Kelly, Britain and the Persian Gulf, 1790-1880 (Clarendon Press, 1968), 576-637.

${ }^{36}$ Hamerton to the Secretary to the Political Department, Government of Bombay, 13 July 1841, Maharashtra State Archives, Political Department, vol. 41/1261, compilation 316.

37 Hopper, Slaves, 150.

38 Dr. Seward, Acting Political Agent, Zanzibar, to Secretary to the Government of Bombay, 4 Aug. 1866, and 4 May 1867, Zanzibar National Archives, AA3/26.

39 Turan Kayaoglu, Legal Imperialism: Sovereignty and Extraterritoriality in Japan, the Ottoman Empire and China (Cambridge University Press, 2010), 23-28.
} 
realize in their treaty relations with the sultan and his family: a singular sovereign who exercised authority over broad swaths of territory, rather than countless jurisdictions run by separate strongmen who nominally submitted to the suzerainty of a distant overlord. ${ }^{40}$ Sovereignty around the Indian Ocean world was a matter of constant negotiation by a range of different "political" actors, very few of whom exercised any strict territorial jurisdiction. The contrast with the Westphalian sovereignty that British officials and others hoped to see could not have been starker.

Nothing reflected this more clearly than the proceedings of the Brussels Conference and the resulting Brussels Act of 1890, an agreement among the world's most powerful states to put an end to the African slave trade. ${ }^{41}$ Of the one hundred articles to the Brussels Act, nearly half were devoted to the "suppression of the sea-borne slave trade," specifically in the Western Indian Ocean, "the maritime zone in which it still exists." The suppression of the slave trade in that region, the Act made clear, hinged on a particular geopolitical imaginary of sovereign states with full jurisdiction over their populations, the very sorts of states that British officials worked to realize around the Western Indian Ocean. That officials, and later commentators, would call the case that went to The Hague the Muscat Dhows case (rather than the Suri Dhows case, which would have been more accurate) reflects these ambitions.

In the effort to pin down an ever-elusive vision of sovereignty, the matter of flagging had to be reckoned with; the practice of granting flags to all who requested them for purposes of convenience could not continue. The Brussels Act clearly signaled an attitudinal shift surrounding the granting of flags to nonEuropeans. Articles 30 to 41 set out a series of rules "for the grant of the flag to native vessels." These were defined as vessels that "present the outward appearance of native build or rigging" or were "manned by a crew of whom the captain and the majority of the seamen belong by origin to one of the countries on the coast of the Indian Ocean, the Red Sea, or the Persian Gulf"- so "dhows" in the broadest sense of the term. ${ }^{42}$ The next twenty articles established the procedures by which vessels suspected of "fraudulent use of a flag" or participation in the slave trade might be stopped, searched, and tried in court.

\footnotetext{
${ }^{40}$ Harms, "Introduction," in Robert Harms, David Blight, and Bernard Freamon, eds., Indian Ocean Slavery in the Age of Abolition (Yale University Press, 2013), 9.

${ }^{41}$ The parties to the agreement included Austria-Hungary, Belgium, the Congo Free State, Denmark, France, Germany, Italy, the Netherlands, the Ottoman Empire, Persia, Portugal, Russia, Spain, Sweden-Norway, the United Kingdom, the United States, and Zanzibar. On the Ottoman Empire and the abolition of slavery, see also William Gervase Clarence-Smith, Islam and the Abolition of Slavery (Oxford University Press, 2006), 98-150; Ehud Toledano, Slavery and Abolition in the Ottoman Middle East (University of Washington Press, 1998), 112-34.

${ }^{42}$ Brussels Act, Article 31. Erik Gilbert notes that this "represented a first step towards making the dhow trade legible"; Dhows, 70.
} 
The Act clearly laid out the criteria that dhows had to meet in order to legitimately acquire a European flag. First, the fitters-out or owners of the vessel had to be subjects or protégés of the power whose flag they carried. Second, they had to prove that they owned real estate situated in one of the power's possessions, or "supply a solvent security as a guarantee of the payment of the fines which might be incurred." Finally, the fitter-out, owner, and captain all had to be of a "good reputation," namely, they could never have been condemned for trading in slaves. ${ }^{43}$ The authorization to fly the flag had to be renewed every year, and the dhow captain would have to supply, inter alia, a crew list in which every "negro ... engaged as a seaman" had been questioned. ${ }^{44}$

The implications of the new requirements for granting flags to dhows were clear. Through the text of the Brussels Act, the signatories-which included France, though it would only ratify the Act two years later, in 1892-agreed that the indiscriminate use of flags to extend an empire's influence would no longer be tolerated. Flag-holders had to be tethered to a discreet political geography, that of the flag state, which could then be held accountable for their actions. The Act made it clear that the successful suppression of the slave trade depended on the ability to close the gap between a Westphalian international order and a frustratingly mobile population. By the end of the nineteenth century, then (and right around the time that the tensions that led up to the Muscat Dhows case began to magnify), mariners, local rulers, and imperial officials all began to see clear steps toward the establishment of a more closely regulated seascape.

\section{ANCHORING EMPIRE}

So much for the grand narrative and the geopolitical transformations that accompanied it. But what if we look a little closer to the ground - or to the sea, as it were? Does it hold up nearly as well? Or would we begin to see the seams in a narrative that has been presented as perhaps a little too authoritative?

Viewed differently, this juncture might look less like a moment of increasing constraint and more like one of high contingency. We know now what the outcome looked like: more clearly delineated states that could often exercise clear jurisdiction within their territories. However, instead of projecting the outcome back onto the actions of Suri nakhodas, so that their actions appear to violate international norms, we need to understand that at this moment it was still unclear what the political landscape (and seascape) was going to look like. This allowed actors like the Suri nakhodas to be more creative in their thinking, to make use of flags and papers in ways that would shape

43 Brussels Act, Article 32.

44 Ibid., Articles 33-35. 
whatever regime emerged, and make imaginative claims as to what that regime might look like, both on land and at sea.

Fortunately, we have sources that allow us to see all of this in action, and they come from the most unlikely of situations. As part of his strategy to win the Suri nakhodas over, the Sultan of Muscat, Sayyid Faisal bin Turki-Sa'id's grandson, who maintained a close association with the British governmenttraveled to the dhow port in June 1900, where he met with mariners who had taken French flags and papers, which they called aqwāl (sing. qawl, or declaration). In their argument to the court at The Hague, the British suggested that the meeting resulted in "a written undertaking signed by these persons to return any French flags held by them at the beginning of the coming year." British officials claimed that the sultan formally accepted the agreement and, on 15 June, "issued a notice warning his subjects against taking flags from foreign governments whereunder they claimed so-called protection." 45

The original Arabic notice reads slightly differently. In it, the sultan stated that his subjects had "misunderstood the taking of flags and passes (aqwāl) of foreign countries as a means similar to granting of protection (wa-biwasilatuhumā al-mutashābihatān himāyathumāa)," and said this "was true of the past but will not be for the future." Claiming that this was a violation of the rights and operations of subjecthood (bi-khilāf al-huqūq wa 'amal al-ra 'iyya), he declared that "I do not recognize flags and papers in my dominions ( $l \bar{a}$ a 'tarif fi mamālikunā al-bayāriq wal-aqwāl)" and that he would not permit the practice after that day without permission from him and "written authorization according to agreements between his states and the concerned foreign governments." 46 The difference in language is important: whereas the British summary of the notice assumed away the sultan's authority to make such a declaration, the sultan's notice was more tentative, and suggests that the jurisdiction they had ascribed to him had not yet taken shape.

The importance of the moment, however, was less in the framing of the outcome than in the sultan's actions during the meeting and their immediate consequences. When he met the mariners, the sultan and his armed retainers forcefully confiscated the Suri nakhodas' papers. However, rather than prompting the immediate surrender of French protection, the confiscation had a more predictable effect: Suri nakhodas immediately went to the French consular and petitioned him for the restitution of their titres. ${ }^{47}$ This moment is fortuitous for historians because it generated a unique set of documents wherein Suri nakhodas articulated, in writing, what they imagined those papers as signaling. Through their petitions, historians can glean a sense of how and why Suri

45 Case on Behalf of the Government, 15-16.

46 Ministère des Affaires Étrangères (hereafter MAE) Muscat Series, vol. 28, 5.

47 For background on the French consulate in Muscat, see Lorimer, Gazetteer, vol. 1, 546-50. 
captains imagined themselves as protégés of the French Empire, and what work they imagined French papers did for them in a world of increasing regulation.

The sources, of course, are not without their limitations. First, they are few in number: of the community of nakhodas in Sur, only nineteen seem to have petitioned the French consul (the case itself involved twenty-six) and it is difficult to ascertain what their relationships were to one another beyond their having come from the same locality. Moreover, their petitions emerged out of a dialogue - on one hand with the Sultan of Muscat, who sought to curb their actions, and on the other with the French Government, with whom they were trying to confirm their status as protégés (they use the term taṣhīh; literally, confirmation, though of their papers). The nakhodas' statements cannot be read as unmotivated, unmediated speech; we cannot decipher their legal consciousness at work, but only their attempts to make claims to French protection through language that they hoped would be effective.

Yet all is not lost. We find breaches in the fabric of normalcy-in the predictable language that Suri captains used to petition French officials. The petitions are delightfully idiosyncratic and there is nothing to suggest that they might have been prepared by someone else. No two statements look the same, and every petitioner took the time to emphasize his own relationship to the French government and his own needs. Others offered narratives of their meeting with the sultan, going so far as to recall verbal exchanges with him regarding their right to French papers. All of the petitions fill the reader with surprise or bewilderment at the claims they make, the geographies they locate themselves in, and the language they invoke. For all of the posturing that their petitions involved, and for all of the distortions of intent that the genre of the petition brings with it, one can see in them a rich legal-historical consciousness at work, a legal culture at sea, steeped in history.

A closer look at the statements that Suri nakhodas made and the behavior they engaged in around the Western Indian Ocean cannot reveal an unmediated "truth" about dhows, empire, and the Indian Ocean, but it can reduce our puzzlement at their actions and the statements they made about themselves and their lives. By reframing these within the context of a changing political and legal geography, we reclaim the contingency of that moment in world history and re-establish it as a one in which these actors could begin to think more creatively about what an imperial seascape might look like.

ON LAND AND AT SEA

For all of their idiosyncrasies in presenting themselves to the French consul, the nakhodas mobilized common themes in their petitions. All but the tersest petitions invoked the idea that the French would protect them "on land and at sea" ( $f i$ al-barr wa fi al-bahr) a capacious and robust protection regime that was infused with historical meaning. The phrase was not incidental, but rather grounded in a long-standing discourse on the right to sail the seas without 
harassment. If we engage in philology - connecting their standalone utterances to an established discourse - and also read them in the context of their other statements, we can begin to see how an abstract claim to the freedom of navigation might anchor itself in a changing imperial legal geography, but also a deep historical consciousness. Part of the process of consuming the titre was incorporating it into a preexisting graphic ideology: making sense of it against the backdrop of a long history of encounters with empire at sea and the place of dhows and instruments like titres within it.

The phrase "on land and at sea" was by no means a ubiquitous one in Muslim legal discourse, but it does appear often enough to give us a sense of what it might have meant to the nakhodas. It was undoubtedly a loaded phrase, intimately linked to claims surrounding the freedom of navigation. ${ }^{48}$ It was not uncommon in early Islamic treaties, in which the Prophet Mohammed granted safe passage "by land and by sea" to neighboring tribes. That notion would be replicated in other early and medieval Islamic treaties from the Arabian Peninsula and the Mediterranean. ${ }^{49}$ More importantly, the phrase appears frequently enough in the thirty-two or so verses in the Quran that mention the sea, and all in connection to matters of navigation. ${ }^{50}$ The verses read: "And it is He who placed for you the stars that you may be guided by them through the darkness of the land and sea"; "It is He who enables you to travel on land and sea..."; "A2 "And We have certainly honored the children of Adam and carried them on the land and sea..."; 53 and "Is He [not best] who guides you through the darkness of the land and sea and who sends the winds as good tidings before His mercy?"54 Taken together with its usage in treaties, the phrase's association with the freedom of navigation emerges more forcefully.

Though it is unlikely that Suri nakhodas would have been privy to the use of the phrase in early and medieval treaties, they might well have read or perhaps even memorized the verses in which the phrase appeared in the Quran. Throughout the Islamic world, the Quran formed the foundation of any education; children learned to read and write using the Quran, and only a minority progressed very far beyond it. Nakhodas, of course, would have had to learn arithmetic, but they would have also been exposed to similar

\footnotetext{
48 Here I am drawing exclusively from Hassan Salih Khalilieh's still unpublished "The Free Sea: Freedom of Navigation and Passage Rights under the Islamic Law of the Sea." I am grateful to the author for allowing me to consult his valuable manuscript.

49 Ibid., 41, 67-68.

50 Ibid., 21-22. On Mediterranean treaties, see Michele Amari, I Diplomi Arabi del R. Archivio Fiorentino (Dalla Tipografia di Felice le Monnier, 1863), 231-32, 233, 234. I thank an anonymous $\mathrm{CSSH}$ reviewer for this reference.

51 Holy Quran, verse 6:97.

52 Ibid., 10:22.

53 Ibid., 17:70.

54 Ibid., 27:63.
} 
curricular foundations. ${ }^{55}$ Furthermore, in a community as bound to the sea as the Suris were, it is inconceivable that the verses that invoked the sea would have passed without comment. Their usage of the phrase "on land and at sea," then, drew on a centuries-old discourse on the freedom of navigationor more precisely, on the place of an overlord in guaranteeing this freedomeven if it only alluded to it in the most general way, taking it out of its specific context and using it to address new concerns. In the Quranic verses, Allah was the supreme protector of those who traversed the sea; in the nakhodas' petitions, the mundane power to protect manifested itself in the person of the French consul.

But Suri nakhodas were not articulating an abstract right to the freedom of navigation; theirs was a claim made within a specific context. Virtually every mariner began his statement with a reference to the threat that British men-of-war (Arabized as manāwir) posed to their mobility. "All of this happened because of fear of British manāwir," claimed one nakhoda, "Abdullah bin Khamis. Another, Salim bin Musallam, stated that they were "afraid of the English manāwir and ... wanted them to go away and let us breathe (aradnāhā tughību 'annā wa natanaffas). $"{ }^{56}$ Others articulated the fear of British manāwir "coming up on us" (târih 'alayna) in different ways. ${ }^{57}$

The characterization of British cruisers in the Indian Ocean as manāwir, or men-of-war, was as revealing as it was curious. While the term ostensibly signaled little more than a type of ship, it had much deeper connotations. Few, if any, of the British ships patrolling the Western Indian Ocean at the time were men-of-war; the bulk were "cruisers," which were lighter, more agile vessels better suited for the purposes of dhow-chasing. Of course, nakhodas might have been unable to distinguish between the two or might have used manāwir to refer to British ships generally. But even then, the category remains a meaningful one. Read differently, the term manāwir opens the doors to a much longer history of European patrol ships at sea, starting with the Portuguese men-of-war and carracks of the early sixteenth century, who sought to redirect local shipping to Portuguese-controlled ports through a regime of safe-conduct passes called cartazes. The Portuguese were vilified by Arabs and Europeans alike for their aggressive attempts to enter the Indian Ocean trading arena, and their arrival prompted calls for jihad and for a united front of Muslim and Hindu rulers against the Frankish scourge. ${ }^{58}$

\footnotetext{
55 See also Roman Loimeier, Between Social Skills and Marketable Skills: The Politics of Islamic Education in 20 $0_{56}^{\text {th }}$ Century Zanzibar (Brill, 2009).

56 MAE Muscat Series, vol. 28, 21.

57 Ibid., 20-21.

58 See also Engseng Ho, "Empire through Diasporic Eyes: The View from the other Boat," Comparative Studies in Society and History 46, 2 (2004): 210-46; Giancarlo Casale, "Global Politics in the 1580s: One Canal, Twenty Thousand Cannibals, and an Ottoman Plot to Rule the World," Journal of World History 18, 3 (2007): 267-96. For contemporary polemics against the Portuguese,
} 
To Suri nakhodas, British ships patrolling the region might have seemed little different from those of a Portuguese imperial past: they routinely harassed dhows around the Indian Ocean on the slightest of suspicions and frequently mistook free merchants for slaves and sent them away as "prize negroes" for whom they would receive a cash payment. ${ }^{59}$ Moreover, because of regulations that cruisers would have to contend with on the shore, captured dhows were likely to be burned at sea rather than returned to Zanzibar, Aden, or Bombay to be tried at a Prize Court. Naval officers often stole from the dhow crews' money and other personal effects. ${ }^{60}$ In short, the entire process would have looked like an imperial racket or like "semi-legal piracy," much as scholars have characterized the Portuguese cartaz system. ${ }^{61}$ In calling them manawwir, Suri mariners brought British cruisers into a turbulent history of Omani encounters with Europeans at sea, and of the crisscrossing webs of imperial alliances and regulations that shaped dhow itineraries in the Indian Ocean. When Salim bin Musallam declared that he "wanted them [the British manāwir] to go away and let us breathe," he was drawing a parallel between Portuguese efforts to squeeze dhows out of local shipping circuits and British attempts to similarly cut into their livelihood.

To counter the threat that British cruisers posed, Suri mariners made a claim to some form of long-standing French protection: twenty, thirty, or even fifty years, or, more commonly, "from the days of our fathers and forefathers." 62 The claim to protection "on land and at sea" was not articulated in the abstract, but with specific reference to French power. In more than one instance, mariners referred to protection given in the name of the Emperor Napoleon (al-qayșar Nabōleōn). Presumably they meant Napoleon III, who by 1900 had been dead for twenty-seven years, but whose memory as a stalwart enemy of the British and architect of a French overseas empire in the Indian Ocean lived on in the mariners' historical imagination.

One of the more revealing petitions in the collection preserved in the French record was by Mohammed bin Sulaym bin 'Abood, who took the time to supply an extended narrative of his meeting with the sultan, recounting precisely the exchange between them on the relative benefits of French and British protection, as well as the attempts by the sultan to force the Suris to

see Zainuddin Makhdoom, Tuhfat al-Mujāhidīn: A Historical Epic of the Sixteenth Century, translated from the Arabic with notes by S. Muhammad Husayn Nainar (Islamic Book Trust, 2006); Hugo Grotius, The Free Sea, Translated by Richard Hakluyt, with William Welwod's Critique and Grotius's Reply, David Armitage, ed. (Liberty Fund, 2004).

59 Hopper, Slaves, 161-77.

60 Gilbert, Dhows, 61-65; records from the Zanzibar Vice Admiralty Court attest to this as well.

61 Gilbert, Dhows, 62; Sebastian Prange, "A Trade of No Dishonor: Piracy, Commerce, and Community in the Western Indian Ocean, Twelfth to Sixteenth Century," American Historical Review 116, 5 (2011): 1269-93, esp. 1280-83.

62 MAE Muscat Series, vol. 28, 20. 
give up French subjecthood. His exchange with the sultan articulated this antiBritish imaginary most explicitly. When the sultan suggested to him that the French would not stand up for the Suris against the British, the mariner retorted, "O Sayyid, do not belittle the French State if you do not know it, for we know that it is not weaker than that state that you came with [the British], and it is stronger in its cannons and manāwir and soldiers." He then asked the sultan if he knew of "the Turkish state" (dawlat al-turk), and when the sultan replied in the affirmative, Bin 'Abood told him, "It [the French state] is of that strength and more." 63 Through an invocation of the strength of the Ottoman Empire, which had for years reached out to maritime communities around the Indian Ocean in an attempt to establish a regional metasovereignty, ${ }^{64}$ Bin 'Abood highlighted the mariners' hope that by allying with the French they might form a counterweight to British hegemony, both in Oman and in the Western Indian Ocean more broadly.

Central to Bin 'Abood's claim to French subjecthood was his notion of place. In his conversation with the Sultan of Muscat, Bin 'Abood declared that he and his family "have in Bukīn [Madagascar] wealth and children and homes," emphasizing that "since I have been of sound mind (min hafazt $a l$ - $a q l$ ) I have been under French protection, and my residence is in Bukīn." ${ }^{65}$ Despite his presence in Sur, Bin 'Abood could locate himself and his family squarely within a French possession in the Indian Ocean. This was not merely posturing, since the nakhoda did have a long history of movement between Sur, Zanzibar, and the French islands in the Indian Ocean. ${ }^{66} \mathrm{He}$ was hardly alone, and a number of other Suri nakhodas made similar claims in their petitions. One, Khamis bin Musallam, claimed that he had lived in Madagascar for nearly thirty years starting as a child and that his father had passed away there; he added that he had been employed by the French in Mauritius, Nosy Be, and Mayotte. ${ }^{67}$ Still others claimed to own property or have family in the Comoros Islands or Djibouti. ${ }^{68}$ By contrast, not one of the Suri nakhodas claimed any sort of allegiance to the Sultan of Muscat, who exercised nominal jurisdiction over the port of Sur.

The Suri mariners' claims to different forms of transregional belonging are difficult to comprehend within a geographical imaginary that sees the port of Sur as an appendage of the Sultanate of Muscat. The national historiography of Oman offers nothing on the subject, and what little writing there is on Sur highlights its maritime past, but roots it firmly in the spread of Arab and

63 Ibid., 21.

64 Casale, "Global Politics."

65 MAE Muscat Series, vol. 28, 21.

66 Abdul Sheriff, "Sur: The World of a Dhow Port," Journal of Oman Studies 13 (2004): 99-112.

67 MAE Muscat Series, vol. 28, 20.

68 Ibid., 19-20. 
Islamic culture abroad. There is nothing to suggest that Sur's history is any different than Oman's, nor do any historians discuss the possibility of it being an independent or quasi-independent port city. ${ }^{69}$ Yet this characterization clashes with the history of Sur itself, as seen from the ocean. Sur was a quintessentially maritime town, the whole of its population oriented toward the sea. Even as late as 1967, a British oil company employee in Oman could visit Sur and say of his meetings with inhabitants, "The talk tended to be of the outside world, at least as far as India, the Arabian Gulf, and East Africa." ${ }^{, 70}$ Even the author of a nineteenth-century Zanzibari legal treatise on the sultan's jurisdiction was careful to refer to them as the "Wasuri" (the Suris) and distinguish them from other Omanis (called "Wamanga") that visited the island. ${ }^{71}$

Suri claims to residence, family, and wealth in French islands around the Indian Ocean were more than a flimsy attempt to place themselves under French protection. In part, they highlighted the sense that these were people steeped in a largely oceanic existence. Though they spent much of their time on land, their life was one of raised sails and lifted anchors. The French Empire was conceived of as a network of islands and port cities that stretched out across the Western Indian Ocean - a sense of power that might not have been entirely de-territorialized, but which grounded itself at certain stations along established traffic lines. What Bin 'Abood and other nakhodas were articulating, then, was a spatial imaginary that wove the itineraries of Suri dhows into the ports and sea lanes through which French imperial ambitions pulsed - a geography that they could trace out with the titre.

As members of an itinerant commercial community that moved dates, mangrove poles, and other goods around the Western Indian Ocean, Suri nakhodas had plenty of opportunity to attach themselves, however temporarily, to the French islands that their petitions recalled. Suris and other Omanis had been active participants in the late eighteenth-century transport of slaves from East Africa to French Mascarene Islands during the sugar plantation boom, and of these some had migrated there and established sugar, vanilla, and coffee plantations. ${ }^{72}$ Others had registered themselves in Mayotte from as early as 1863 . One kept a wife in the Comoros and had registered himself there in 1880. Still another spent his life shuttling between family members in the Comoros, Pemba, Madagascar, and the Gulf. ${ }^{73}$ The very place names

${ }^{69}$ See, for example, the edited volume Sür 'Abar Al-Tärīkh (Oman Ministry of Heritage and Culture, 2007).

${ }^{70}$ Ian Skeet, Muscat and Oman (Faber, 1975), 81.

${ }^{71}$ Katryn Bromber, ed. The Jurisdiction of the Sultan of Zanzibar and the Subjects of Foreign Nations (Ergon Verlag, 2001), 23-25.

${ }^{72}$ On the slave trade to the Mascarene Islands, see also Abdul Sheriff, Slaves, Spices, and Ivory in Zanzibar (James Currey, 1987), 41-48; C. S. Nicholls, The Swahili Coast: Politics, Diplomacy, and Trade on the East African Littoral, 1798-1856 (George Allen \& Unwin Ltd., 1971), 103, 199-200.

73 Abdul Sheriff, "Sur." 
that Suri mariners used to identify islands in the French Indian Ocean-Bukinn for Madagascar, or Ngezeja for Grand Comore, for example — suggests a familiarity that could emerge only from a much longer history of movement between south Arabia and the southwestern Indian Ocean.

Yet there was more to Suri statements than an abstract sense of transregional belonging, however plausible they may have been. These were also legal claims. By signaling that they owned property or had family in French possessions, they were articulating claims to domicile in those islands and by extension the right to fly the French flag or possess French papers. In their claims, they explicitly addressed two of the three requirements set out in Article 32 of the Brussels Act: that the fitters-out or owners of a ship flying the European flag had to be either a subject or a person protected by that country, and be able to prove that they owned real estate situated in one of that country's imperial possessions. That their appeals to the French consul were couched in the same terms suggests an international legal consciousness that truncates the distance between the negotiating tables in Brussels and the decks of the Suri dhows. ${ }^{74}$

\section{IN STATUS AND IN WEALTH}

This is all good, but still somewhat abstract. Suri nakhodas' claims to the right to navigate the seas without harassment may help uncover the legal-historical consciousness that animated their consumption of the titres, but they tell us little about how they used the titres and flags themselves, how they fit them into a broader repertoire that they mobilized to shape the contours of a changing world of empire and law. This was part of how Suris interacted with this changing seascape, not simply as a product of historical forces that they would protest in writing, but also as a legal regime that they could navigate through their ingenious uses of imperial paper technologies.

In claiming French protection "on land and at sea," Suri nakhodas were trying to navigate the changing tides of an international legal order, translating it into terms that had more meaning to them regionally. The French titres, as the material manifestation of an international legal regime, constituted the basic artifact by which they understood a changing body of international law as taking shape on the high seas, but titres were also a tool with which they could make that regime work for them. As international diplomats constructed a new regulatory seascape based on attachments to land and sovereign states, these mariners used the instruments of that order to make spatial and legal claims of their own. Their consumption of the titres sought to produce realities

\footnotetext{
74 It was also a legal strategy that would have been familiar to them: in the 1850 s, Indian merchants in the Persian Gulf and East Africa had made similar claims to British subjecthood by highlighting similar connections that they maintained in India. See also Bishara, A Sea of Debt, 114-49; Sheriff, Slaves, Spices, 201-7.
} 
that were separate from the processes and structures that produced those documents, realities that ran below their winds rather than against them.

But there was more. When Suri mariners made claims to French protection "on land and at sea," they often coupled it with another notion: that French protection would extend to their person and property, a protection "in status and in wealth" (fil-hāl wal-māl). The nakhoda "Abdullah bin Khamis bin 'Ali appealed to the "high government of France for that strong protection with which no one will molest us, not on land and not at sea, and in status and wealth, and all that concerns us."75 Another nakhoda, Salim bin Musallam bin Rabi', extended that protection further, invoking a protection that was "always on land and at sea" and which extended to "my sons after me.",76 Protection involved the legal transmutation of people and property between legal regimes, not just an abstract relationship between an empire and a protégé, and at sea, flags and passes were central to this process, much as they had been in the past.

One particular incident illustrated how this notion might be operationalized. In 1904, two dhows collided in the harbor at Dubai, resulting in heavy damages to one of them, which belonged to 'Ali bin Salim bin Mohammed, an Omani from a town near Muscat who claimed French subjecthood. When it fell to the $q \bar{a} d i$ at Dubai to sort out the liabilities, it was found that it was 'Ali's late father who had held a French titre; when Salim passed away, 'Ali inherited the dhow and the titre along with it. Immediately after the collision, 'Ali lowered the French flag from his damaged dhow and hoisted it on another dhow that he had bought as a substitute. ${ }^{77}$ A British intelligence officer commented on this phenomenon years later, noting that "the privileges were attached to the vessels, of which the owners and crews were continually changing" and that this made it "impossible for the Sultan to know how many and what persons might claim protection under a single certificate.",78

'Ali bin Salim might not have been from Sur itself, but his actions would have been legible to members of the Suri nakhoda community. In one petition, the nakhoda Rashid bin Khamis requested a titre for a dhow that he had just bought, which would replace the titre he had handed off to a person in Zanzibar who had just bought his old dhow. The titre, it appeared, was transferred along with the dhow itself. In another petition, the nakhoda Sulaym bin Jum'a bin Sulaym narrated how his father had been a French protégé for more than thirty years before passing away, and that he himself had become a French protégé after his father's death. Bin Sulaym's titres, it seemed, were no longer in his possession. He had sold his old dhow and remained without

${ }^{75}$ MAE Muscat Series, vol. 28, 21.

76 Ibid.

77 Case on Behalf of the Government, 21.

${ }^{78}$ Lorimer, Gazetteer, vol. 1, 549. 
one for nearly two years. Although he had just recently purchased a share in a new dhow, the titre was in his partner's name, not his. After asserting that "people know that this boat is mine" and expressing a fear that something might happen to him at the hands of the British or the ruler, he concluded his petition by requesting French protection that was "strong for wealth and status, on land and at sea" (wa takūnu himāya qawiyya fì al-māl wal-hāal fil-barr wal-bahar). ${ }^{79}$

The fluidity with which mariners approached these instruments and the jurisdictional mobility they enabled was illustrated by the movements of the titres from father to son, seller to buyer, and partner to partner through the medium of the dhow, and from one dhow to another under the command of a nakhoda. As paper technologies, the titres were written manifestations of the forms of protection that mariners sought, and of the legal geographies that they imagined themselves as inhabiting. But also because they were on paper, they took on a material form that protection itself could not, and thus they could be integrated into the circuits of exchange that bound Suri nakhodas to one another. In the nakhodas' use of the titres in certain moments we can see a sense of how that status, instantiated as it was in a set of documents, could transfer through people and property, "in status and in wealth," as it were.

There was nothing on the paper itself that envisioned this negotiability. The papers themselves were unremarkable in their appearance, being a printed form with the words Titre de Navigation sous Pavillon Francais, Valable Pour Un An (Certificate of navigation under the French flag, valid for one year) emblazoned across the top. The document, which limits its scope to "ships referred to as dhows" sailing exclusively in the Indian Ocean, lists the name, dimensions, and tonnage of the dhow, as well as the name and residence of the owner and captain. It goes on to grant the captain the right to sail under the French flag within a circumscribed area (usually the Persian Gulf, the Red Sea, and the Indian Ocean) and "with the ability to have a crew made up of foreigners." The protection it afforded was summarized at the end of the document, in which the French government "prays and requires all sovereigns, states, friends, and allies of France and their subordinates" to allow the vessel free passage without disturbance or impediment.

The gap between what the titre declared and what nakhodas imagined it to do is immediately obvious. Neither the statements nor the actions of nakhodas suggested that any one of them might have thought of the titre as being valid for only a year or limited to a single captain. On the contrary, they appear to have understood the rights that the titre bestowed upon them as extending indefinitely into the future, that it at least encompassed members of their family as well, and that it could transfer to people that were unrelated to the nakhodas

79 MAE Muscat Series, vol. 28, 20. 
through a simple sales transaction. The dhow that the rights attached to also seemed incidental; nakhodas indiscriminately shifted their titres from one dhow to another, despite the restrictions expressed on the document itself. There appeared to be a yawning gap between what the titre declared and how the nakhodas mobilized it.

But perhaps the gap we perceive might be a matter of a perspective grounded in an imperial legal episteme. To get at how these passes and their attendant rights might have been approached by nakhodas, it is not enough to read the French titres on their own. In fact, nakhodas would not have seen these as isolated instruments, but as one expression of a broader genre of safe conduct passes that stretched from the past to the present and from the local to the imperial. To understand their consumption of the French titres, therefore, we must view titres as forming one part of a broader documentary repertoire and grasp how nakhodas domesticated these tools of imperial surveillance into their own knowledge economies.

When the Suri nakhodas spoke in the same breath of their titres (which they called their $a q w \bar{a} l$ ) and the threat of British manāwir, their statements alluded to their encounters with the Portuguese men-of-war that had tried to assert their sovereignty over the Indian Ocean by forcing safe-conduct passes (cartazes) onto local ships. ${ }^{80}$ The rough analogies between the Portuguese cartazes and the French titres in framing the relationship between empires, local shipping, and safe passage would not have been lost on the Suris, whose utterances mutedly invoked this past. The Portuguese cartazes, of course, aimed to protect local shippers from the Portuguese themselves, while the French titres effectively aimed to protect them from another European power, but it would be a short step from the one to the other.

But one might move spatially as well as temporally. Just a few hundred miles up the Arabian coast from Sur, in the dhow port of Kuwait, nakhodas carried their own papers, called aqwāl, issued by that port's ruler. Like the French titres, these aqwāl identified their holders as members of a particular political community, and asked those who searched them to furnish them with the appropriate rights. For example, a qawl issued to two related Kuwaiti nakhodas addressed itself to "those who traverse the seas and reside in the ports, from all of the great, exalted, and friendly nations," and identified the carriers as being "of our associates, the people of Kuwait, and our followers" (min jamā 'atnā ahl al-Kuwayt wa tābi 'nā). The qawl then prayed for "the understanding of the friendly great nations, that if they see and query them, that

\footnotetext{
${ }^{80}$ For a succinct explanation of the cartaz system, see Charles H. Alexandrowicz, An Introduction to the History of the Law of Nations in the East Indies $\left(16^{\text {th }}, 17^{\text {th }}\right.$ and $18^{\text {th }}$ Centuries) (Clarendon Press, 1967), 71-77; and his "Freitas versus Grotius," British Yearbook of International Law 35 (1959): 176-80. I am grateful to anonymous CSSH reviewers for these references.
} 
they treat them suitably, in accordance with the principles and laws, and the ties and bonds, of friendly nations." 81

The language used in the Kuwaiti aqwāl and the French titres were clearly different in terms of who they addressed themselves to and the scope of the rights and privileges they asked for, to say nothing of the fact that the Kuwaiti documents make no mention of flags. The striking thing about the Kuwaiti aqwāl, though, is not the language they mobilize, but rather that they exist at all. That there operated another, similar regime of passes, and that they were called aqwāl, the same term that the Suri nakhodas used for the French titres, points to a much richer phenomenon at play. The French titres did not exist in a legal world on their own, and the Suri nakhodas' use of them was not some legal anomaly. They fit into an already-existing world of safe passes that similarly conferred a legal status onto their holders.

That said, examining the differences between the two passes can help us appreciate the logic behind the mariners' usage of the titres. Unlike the handwritten qawl, the titre was a printed form with blank spaces to be filled in. Its form was entirely a bureaucratic artifact - a product of the emergence of "the personnel state" that had replaced "the personal state" in France after the Revolution. ${ }^{82}$ The titre was thus aimed at managing a distant, more faceless group, and for a limited amount of time. It was an instrument that was meant to be used, not read. ${ }^{83}$ The handwritten qawl, by contrast, articulated a mode of governance that underscored the durable social bonds between a ruler, his subjects, and their family and associates. Its invocation of jamā 'atnā, broadly construed as changing groups of kin and partners that could be considered "associates," and its lack of a time limit, are revealing. ${ }^{84}$ If the nakhodas seemed promiscuous in their transferring of titres to one another through vehicles like families, sales, and partnerships, it is because they imagined them only as part, and perhaps a more fungible part, of a documentary repertoire that was central to navigating the changing oceanic seascape. In referring to them as aqwāl, they were explicitly domesticating them, taking instruments designed to delineate the contours of inter-imperial jurisdiction and grounding them in a world of local/regional paper of a different, but comparable, variety. That world was certainly as much a product of a history of imperial encounters and absorptions as of intra-communal dynamics. Like many others, nakhodas engaged in

\footnotetext{
81 "Historical References," Diwan Marafie < http://www.diwanmarafie.com/En/Doc.htm> (accessed 1 Oct. 2016).

82 Kafka, Demon of Writing, 32.

83 Gitelman, Paper Knowledge, 30-31.

84 On the political community in South Arabia and East Africa, see Peter Lienhardt, "The Authority of Shaykhs in the Gulf: An Essay in Nineteenth-Century History," Arabian Studies 2 (1975): 61-75; C. S. Nicholls, The Swahili Coast (George Allen \& Unwin, 1971), 246-323; John C. Wilkinson, The Imamate Tradition of Oman (Cambridge University Press, 1985), 91-147.
} 
claims to protection at many levels, and often spoke in registers that collapsed the boundaries between the imperial and the local. ${ }^{85}$

That two, parallel systems of safe conduct passes coexisted should not be surprising. Research has suggested that even the Portuguese cartazes, once thought of as an anomaly in an Indian Ocean world of peaceful trade, should be reimagined as fitting within a world of indigenous safe-conduct passes of a similar genre. ${ }^{86}$ The overlapping of local and imperial regimes was thus nothing new, and the language that the Suri nakhodas used to describe the legal-imperial technologies around them, aqwāl and manāwir alike, clue us in to this historical depth. In this respect, one might think of the aqwāl of past and present as collectively forming an entire genre of safe-conduct passes, which could as easily extend to the land as to the sea. ${ }^{87}$ Protection regimes for people and property did not exist in the singular, and the maritime world of Suri nakhodas consisted of a broad gradient of protection circuits of different scales that mariners could circulate within through different forms of paper.

Through their nimble usage of paper on board their dhows, Suri nakhodas were able to move themselves, their families, and their property between the different local and imperial legal regimes, much as they had in the past. Their claims to protection and property were forged at, but also helped to forge, the interstices of a changing legal world, and they mobilized their aqwal to navigate a changing seascape, shaping what the latest global regime might be able to do locally and what local regimes might look like on a broader scale. In a sense, they took the paper technologies of imperial law, which would later form the basis for international law, and rooted them within a world of regional signs, objects, and histories. Put differently, they domesticated international law.

POSTSCRIPT: GLOBAL AFTERLIVES AND DEAD LETTERS

There is an easy way to read the Muscat Dhows case, placing it within the context of the debate surrounding the regime of flags of convenience. And indeed, the case's life and afterlives might justify that reading: in the award handed down by the Permanent Court at The Hague, arbiters agreed that France had the right to grant flags and passes before 1892, the year the

\footnotetext{
85 Lauren Benton and Adam Clulow, "Empires and Protection: Making Interpolity Law in the Early Modern World,” Journal of Global History 12 (2017): 74-92.

86 Prange, "A Trade of No Dishonor," 1276; Luis F.F.R. Thomaz, "Precedents and Parallels of the Portuguese Cartaz System," in Pius Malekandathil and Jamal Mohammed, eds., The Portuguese, Indian Ocean, and European Bridgeheads, 1500-1800: Festschrift in Honour of Professor K. S. Mathew (Tellicherry, 2001), 67-85.

87 The qawlnama, which generally referred to treaties between governments, often involved provisions of safe passage by land. See also Gijs Kruijtzer, Xenophobia in Seventeenth-Century India (Leiden University Press, 2009), 84.
} 
French government ratified the Brussels Act in full, and dhow owners who had the right to passes prior to that year retained that right as long as France renewed it. However, passes issued after 1892 were deemed unauthorized unless the holder fit the description of a protégé, as articulated in a series of 1863 acts passed by the Ottoman Empire to which France had assented. Moreover, the tribunal decided that French protection was accorded only to the owner and dhow specified in the pass; it could not pass from one person to another or even one dhow to another, even if the dhows were owned by the same person. Finally, those who had legitimate passes were not exempt from the sovereignty or jurisdiction of the sultan. In sum, the decision confirmed the vision of a Westphalian order on the high seas.

For scholars of maritime and international law, the Muscat Dhows case lived on, first as a subject of extensive commentary in the decade after the case, and then as a footnote in an ever-thickening web of case law, statute, and international legislation on matters of jurisdiction and the law of the sea. The first commentators saw it for what it was, at least on the face of it: a ruling on a matter of extraterritorial jurisdiction. ${ }^{88}$ But at some point the case began to take on meanings that were never associated with it. Commentators read it as upholding France's right to determine its own registration procedures, which fit neatly into the flags of convenience narrative, but may have misread the case itself. ${ }^{89}$ Seen another way, it was only in the afterlives of the Muscat Dhows case that the Suri nakhodas ended up getting their way.

But historians need to go back and rescue the contingency of that moment in world history. At the century's turn, it was not immediately clear what the results of the proceedings would be. Only after legal discourses by British officials, their representatives in The Hague, and later legal scholars were layered onto the case was one particular narrative of legal order in the Western Indian Ocean imposed - a narrative that aimed to protect a vision of global order from the endless possibilities that might have otherwise emerged. More than that, it is a narrative that privileges a particular way of ordering the world, through territorial states with sovereigns who exercised jurisdiction over their subjects. The ship appears an extension of the land, and the hand-wringing we see about flags of convenience grows of out this tension between an imagined world of hardened jurisdictions and an increasingly mobile body of mariners.

But we can step outside of that paradigm and approach the subject from a different perspective. To quote Carl Schmitt: "We name the image that we make of our planet simply our image of the earth, and we forget that there can also be a sea-image of it.... We conceive of a ship on the high seas as a piece of land,

\footnotetext{
88 See also Charles Brunet, Les Boutriers de la Mer des Indes: Affaires de Zanzibar et de Mascate (1910); J. Westlake, “The Muscat Dhows," Law Review Quarterly 89 (1907): 83-87.

${ }^{89}$ See also Powell, "Taming the Beast," 271; Boczek, Flags of Convenience, 100-1; Carlisle, Sovereignty for Sale, xiii.
} 
which sails upon the sea as a 'swimming piece of state domain,'... [but] for maritime humans these are all entirely false transferences sprung from the imaginations of land rats. A ship is no swimming piece of land, as little as a fish is a swimming dog."90 The Suri nakhodas' invocations of land and sea, status and wealth, and all through an interlinked chain of islands and ports around the Western Indian Ocean - all of these pointed to a different imaginary at play in what actors would have all recognized to be a moment of enormous transformation, but also of deep contingency. And it was through their French papers and flags - the very objects that formed the basis of the dispute in The Hague and the subject of debate at negotiations tables in Brussels - that they translated the precepts and instruments of international law into life on the high seas. In a sense, they engaged in a process of domesticating a changing body of international law, using its artifacts to engage in their own claimmaking, and anchoring them in their intimate circuits of exchange and the histories that animated them. When Suri nakhodas invoked and mobilized their $a q w \bar{a} l$, they located them in world history. Their present was not an isolated moment, but one episode in a long history of encounters with empires, local rulers, and protection regimes at sea.

Only later, over the course of the arbitration proceedings at The Hague, did the voices of Suri captains change; a select few creep into the appendices of the case material, mediated by chains of translation and condensation. The voices that frame the case and its implications are those of officials and their arbitrators, who did their utmost to squeeze out any noise. The nakhodas' lives, their imaginaries, and the lengths to which they went to articulate and realize their vision would all become subjugated to a narrative that is both more familiar in its outlines and more comforting in the distinctions it makes between licit and illicit. Writing the "big" narrative of empire and extraterritorial jurisdiction, and ultimately of flags of convenience, necessitated a process of silencing.

So what is to be gained from writing this from a micro perspective? The point is neither to rescue the nakhodas' vision of the world nor to recast them as heroes. Nor is it to frame their actions as some form of resistance to empire, however tempting it might be to do so. Instead, it is to suggest that big narratives like that of flags of convenience might usefully be read from small vantage points. These might give us a sense of how global regimes made sense locally, but also allow us to reflect on other possibilities that existed at the time. One goal in doing microhistory, after all, is to see the range of alternatives that were real and possible at a given moment in time, but which often escaped institutional records or traditional histories.

90 Carl Schmitt, Land and Sea: A World-Historical Meditation (Telos Press, 2015), 79. 
The history of the flags of convenience is an easy place to start: the literature to date has mentioned the Muscat Dhows case only in passing, along with other relevant cases, and has privileged a seamless narrative of legal change and a story of law as an unfolding text, written primarily in courtrooms and legislative halls. But to write a microhistory of the Muscat Dhows case is to write along the seams themselves, to highlight the multiple regimes that overlapped and the ability of actors to draw on their past and present experiences to navigate a changing seascape. It is to center the multiplicity in representations of the world and to elucidate the processes through which only one possibility was imposed onto that arena, recasting alternative visions as either deviant or misleading. This was not law as it was reported in law textbooks; it was a law that was inscribed upon the seascape, by actors that historians have (perhaps too hastily) written off as having no respect for the law. Nakhodas might not have been doing the work of international law in the Indian Ocean, but they were certainly protagonists in its history there. Their work was to take it and ground it within a longer history, so as to seize on possibilities that had not yet been negated.

I will end this article with an anecdote. Inside the gathering hall (diwān) of the Al-Issa nakhoda family in Kuwait is a series of pictures celebrating the family's maritime past: a portrait of the family's patriarch; a picture of five nakhodas gathered in Bombay; a photo of a family's dhow taken in 1917; and another of Bin 'Issa's qawl, issued to him in 1907. The contrast with the global dimensions of the narrative surrounding flags of convenience could not be more striking. In that narrative, the $q a w l$ stands as a dead letter, stripped of any legal history. Absent from the family's narrative was any discussion of empire, extraterritorial jurisdiction, or sovereignty. Visitors are presented instead with a view of the past infused with meaning, a durable braid of people, ships, and papers that celebrate the intimate circuits into which nakhodas had once brought the instruments of international law. 
Abstract: This paper engages in a microhistory of international law, grounded in the contests surrounding the Muscat Dhows case brought by Great Britain against France in 1905. At the heart of the case was the question of whether the French consul had the right to grant flags and navigation passes to dhows from the southern Omani port of Sur that were suspected of transporting slaves. The case became foundational to studies of the law of the sea, and the ruling is still cited in footnotes in law school textbooks. Buried in the case's proceedings, however, are a series of petitions by the dhow captains that give historians a window into the legal imaginaries of Indian Ocean mariners in an age of empire. Through a close reading of the petitions, I explore how captains located themselves within an imperial legal geography, and appropriated legal technologies - passes and flags - to help them shape the legal possibilities of a changing political and economic seascape. I argue that the claims the captains articulated and the practices they engaged in at sea reveal a maritime legal culture at work, one animated by a long history of encountering regional and global empires at sea. Their documentary practices illuminate how they engaged in and domesticated a body of international law, and illustrate how the regime manifested itself in an ocean that ran thick with legal idioms.

Key words: international law, dhows, microhistory, maritime law, Muscat, Zanzibar, Indian Ocean, qawl, titres, flags 